\title{
An assessment of the physicochemical properties and toxicity potential of carwash effluents from professional carwash outlets in Gauteng Province, South Africa.
}

\author{
Memory Tekere*, Timothy Sibanda, and Khumbudzo Walter Maphangwa \\ Department of Environmental Sciences, UNISA Florida Campus, P.O Box 1710, Florida, South \\ Africa
}

Corresponding author*: tekerm@unisa.ac.za

\begin{abstract}
The assessment of the quality of carwash effluents has received scant attention as a potential source of public and environmental health hazard in South Africa as demonstrated by the lack of literature in this subject. The physicochemical quality and potential ramifications of carwash effluents on receiving waterbodies were investigated in this study. Grab effluent samples were collected from six carwash outlets in Gauteng Province of South Africa and analysed for selected physicochemical qualities including biological oxygen demand (BOD), oil and grease, total petroleum hydrocarbons-gasoline range organics (TPH-GRO), $\mathrm{pH}$, dissolved oxygen (DO), total solids (TS) and total dissolved solids (TDS), electrical conductivity (EC), nutrients (nitrates, nitrites and phosphates), anionic surfactants and heavy metals (zinc [Zn], copper [Cu], lead [Pb] and chromium [Cr]). Further, the toxicity potential of the effluent samples was assessed using organisms from four trophic levels ranging from Selenastrum capricornutum (primary producer), Daphnia magna (primary consumer), Poecilia reticulata (secondary-tertiary consumer) and Vibrio fischeri (decomposer). High pollutant levels were observed in all effluents with BOD ranging from $27 \pm 2.1$ to $650 \pm 4.9 \mathrm{mg} / \mathrm{l}$, TDS from $362 \pm 8.5$ to $686 \pm 8.5 \mathrm{mg} / \mathrm{l}$, GRO-TPH from $0.01 \pm 0.0$ to $7.6 \pm 0.2 \mathrm{mg} / \mathrm{l}$, DO from 0.0 to $0.1 \mathrm{mg} / \mathrm{l}$, Zn from $0.79 \pm 0.08$ to $20 \pm 2.12 \mathrm{mg} / \mathrm{l}$, Cu from $0.77 \pm 0.03$ to $13 \pm 0.71 \mathrm{mg} / \mathrm{l}$ and oil and grease from $12 \pm 2.8$ to $43 \pm 2.1 \mathrm{mg} / \mathrm{l}$. Ammonium concentrations ranged from $0.4 \pm 0.1$ to $75 \pm 6.4 \mathrm{mg} / \mathrm{l}$; turbidity from $109 \pm 0.7$ to $4000 \pm 29.7 \mathrm{mg} / \mathrm{l}$, anionic surfactants from $1.4 \pm 0.1$ to $5.8 \pm 0.3 \mathrm{mg} / \mathrm{l}$ and TPH from $<0.01$ to $7.6 \mathrm{mg} / \mathrm{l}$. Toxicity assessment assays resulted in 100\% mortality for fish and Daphnia after 96 and $24 \mathrm{~h}$ respectively and significant bioluminescence and growth reduction in Vibrio fischeri and algae after 15 min and $72 \mathrm{~h}$ respectively. Most of the measured physicochemical parameters were in concentrations above the Environmental Management Agency (EPA) stipulated guidelines. Additionally, the effluents demonstrated acute toxicity against all four test species.
\end{abstract}

Keywords: Carwash effluent, toxicity assay, physicochemical quality, pollutant, surface water

\section{Introduction}

Professional car washes are an easy way for consumers to remove dirt and grime from their vehicles. However, car washing is a highly water-consuming process and involves the use of chemicals, generating potentially toxic wastewater effluents (Zaneti et al. 2012). Effluents from these professional car washes are, by law, supposed to drain into an oil/water separator or 
clarifier for pre-treatment before they are discharged into municipal wastewater treatment works (Mazumber and Mukherjee 2011). However, a study by (Lau et al. 2013) in Malaysia showed that only an insignificant number of car wash stations are equipped with on-site wastewater treatment systems, with many car washes producing effluent whose chemical oxygen demand (COD) levels were beyond the regulatory limit set by the Malaysian government. There is growing public concern for the health and safety of the public water supply as well as the environmental health of freshwater ecosystems like rivers and streams which are the ultimate drains into which these effluents are discharged (Fall 2007). Freshwater ecosystems provide a range of habitats for a significant proportion of the world's plants and animal species (Baa-Poku et al. 2013). Besides effluents from professional car washes (which are subjected to treatment before discharge), effluents from cars that are washed in the street also drain into stormwater systems (Brown 2002). Consequently, stormwater contain a large variety of contaminants including oil and grease which have long been recognized as pollutants which can cause significant environmental damage (Bursztynsky and Scofield 1982). There is, however, an under appreciation of the ecotoxicological potential of effluents from the car wash industry possibly caused by a perception that wastewater from the car wash industry is not as severely contaminated as effluents from other industries (Lau et al. 2013). While this perception may come as a result of previous research work carried out as in the case of a research by Brown (2002) in three regions of the USA, these findings may not be a yardstick of the performance of car washes across the board as the same author also states that “... each car wash owner/operator must be aware of and comply with local discharge limitations.”

Pollutants of concern in car wash effluents include diesel range organics (DROs) like oil and grease, carbon, asphalt, surfactants, salts, detergents, phosphates, ammonium compounds, heavy metals, acids, organic matter and microorganisms among others (Mazumber and Mukherjee 2011; Lau et al. 2013; Mohamed et al. 2014). Some of these pollutants like oil, grease, detergents, heavy metals and ammonium compounds can be directly toxic to aquatic organisms like fish while others like nutrients can cause a shift in ecological balance, should they be improperly managed and discharged (Randles et al. 2007). Oily wastewater contains toxic components such as phenols, petroleum hydrocarbons and polyaromatic hydrocarbons (PAHs) which are inhibitory to plant and animal growth, mutagenic and carcinogenic to humans (Gryta et al. 2001). It has long been established that oil toxicity in aquatic systems is mainly due to the soluble compounds as opposed to dispersed oil droplets (Bursztynsky and Scofield 1982). Larval stages of aquatic organisms are particularly vulnerable to soluble toxic components in grease and oil and in lubricants in general, which also tend to accumulate in at the base of aquatic food chains, ultimately reaching human beings as the contaminants move up the food chain (Diphare et al. 2013). Once in waterways, grease and oil rise to the top and form a film that blocks sunlight, impairs photosynthesis, prevents oxygen replenishment of water bodies and ultimately enhance growth of oil-consuming microorganisms (Diphare et al. 2013). Meanwhile, some surfactants like linear alkylbenzene sulphonates (LAS) are extremely oxygen demanding for their biodegrading and will likely induce concentration-dependent oxygen deficiency in aquatic 
environments in addition to facilitating the permeation of other pollutants into aquatic organisms (Sablayrolles et al. 2010).

Freshwater is a finite resource whose availability in sufficient quantities and quality is key to sustainable development (Haddis et al. 2014). South Africa is a relatively water scarce country whose available freshwater resources are further threatened by pollution emanating from discharge of inadequately treated industrial and municipal effluents into freshwater courses (Ilemobade et al. 2009). There is need to map and assess pollution sources for effective pollution mitigation measures to be put in place. In this regard, numerous studies have been carried out to assess the contribution of municipal sewage discharges in violating the integrity of South Africa's rivers but there is a dearth of information with regards to the contribution of car wash effluents in water pollution in South Africa. The fast growth of car wash service centres as is the case in Johannesburg, Gauteng Province, results in increased contribution of pollution into environmental water bodies (Mohamed et al. 2014). To the best of our knowledge, no studies have previously been carried out to investigate the contribution of car wash effluents to water pollution in South Africa, not least in Gauteng Province. The purpose of this study was to evaluate the quality of car wash effluents from selected professional car washes in Johannesburg Metropolitan area and to assess the toxicity potential of these effluents.

\section{Materials and methods}

\section{Description of study site}

Johannesburg is the capital of Gauteng Province (Rogerson 2002). Ninety-seven percent (97\%) of the population in this province are urban dwellers (SouthAfrica.info 2012). Though it constitutes only $1.4 \%$ of South Africa's total land area, Gauteng is the economic hub of South Africa, contributing more than $33 \%$ to the gross domestic product (GDP) of the entire country (SouthAfrica.info 2012). The economy of Gauteng has since diversified from mining to manufacturing, retail, agriculture, information technology, finance and small and medium enterprises among others. Figure 1 shows the map of Gauteng Province. 


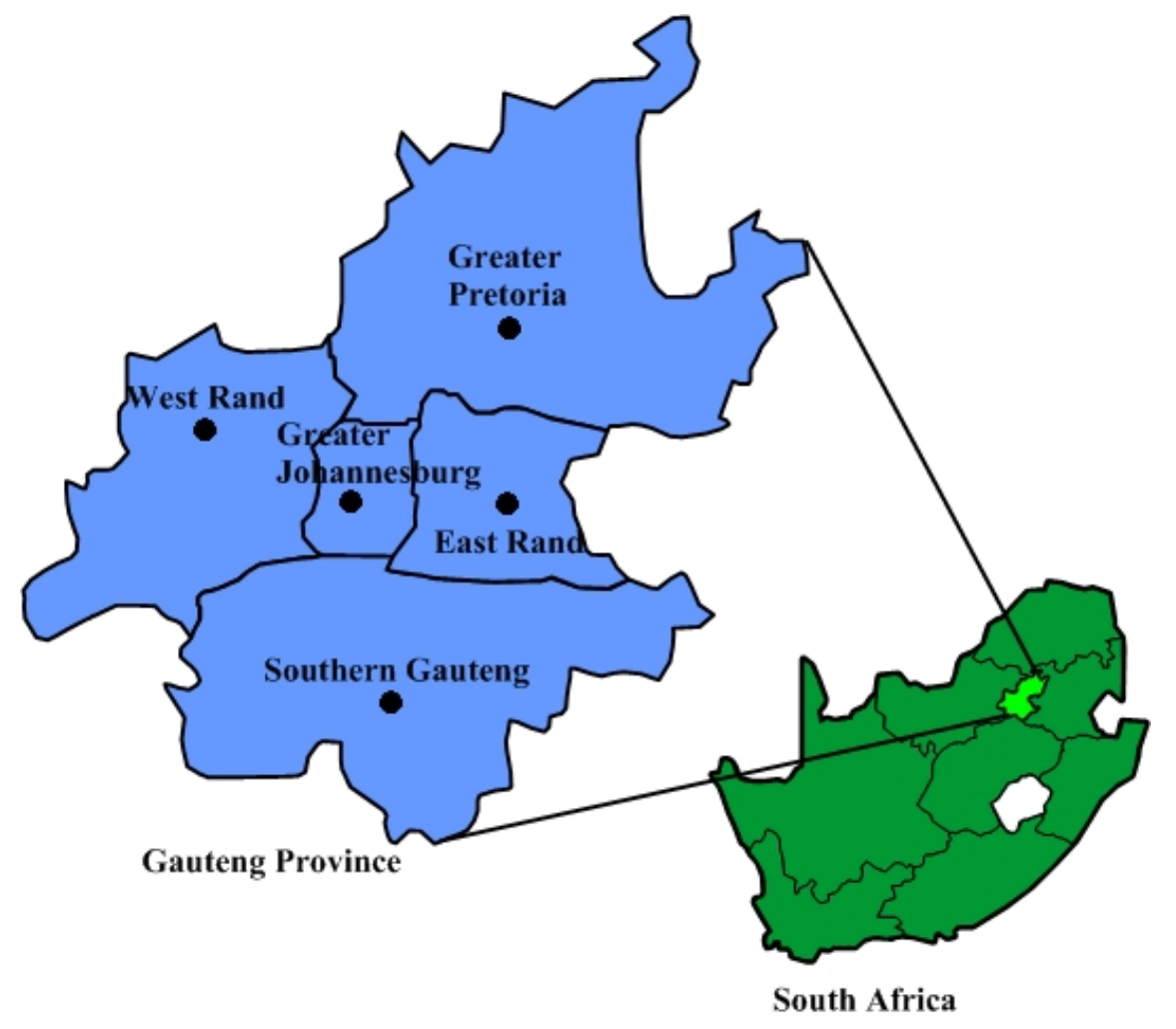

Figure 1: Map of Gauteng Province in South Africa (not drawn to scale).

Gauteng Province has the highest population density in South Africa which in 2011stood at 675 people $/ \mathrm{km}^{2}$, and at current growth rate, is projected to be 859 people $/ \mathrm{km}^{2}$ by 2020 (SouthAfrica.info 2012). The high population density of this province translates to a high number of live vehicles in Gauteng as compared to other South African provinces (ArriveAlive 2010). As of October 2010, the National Traffic Information System (eNaTIS) estimated that there were 9797413 live vehicles in South Africa, 38.89\% (3 809 764) of which were registered in Gauteng Province alone (ArriveAlive 2010). Latest figures from the National Association of Automobile Manufacturers of South Africa (NAAMSA 2015) show that from January 2015 to July of the same year, 356755 new cars had been sold in South Africa. Consequently, carwash outlets are blossoming in the country, but more importantly in Gauteng Province. The number of car washes in Johannesburg Metropolitan alone is estimated to be above ninety. For this study, six sampling sites (carwashes) were selected and designated CW1, CW2, CW3, CW4, CW5 and CW6 (real names and geographical coordinates cannot be given due to a confidentiality clause included in the approved research ethics clearance). However, CW1, 2 and 3 were in Johannesburg City while CW4 to 6 were in Sandton, Sandton City.

\section{Sample collection}


For toxicity screening assays, grab samples were collected in pre-sterilised five litre plastic bottles from each of the six carwash outlets while samples for physicochemical analysis were collected in clean, detergent and chemical free $500 \mathrm{ml}$ bottles. Sample containers were completely filled up, leaving no headspace. Samples were immediately chilled to approximately $4^{\circ} \mathrm{C}$ (in a cooler box containing ice) following collection and transported to the laboratory for analysis within $36 \mathrm{~h}$ of collection, following the descriptions of Marshall (1998). As a quality control measure, and to preserve the integrity of toxicity testing results, the temperature of samples was checked to make sure that it was approximately $4^{\circ} \mathrm{C}$; otherwise higher temperature could lead to the loss of volatile substances and compromise the results.

\section{Sample analysis}

\section{Physicochemical quality assessments}

Physicochemical parameters; temperature $\left(\mathrm{T}^{\circ} \mathrm{C}\right)$, dissolved oxygen (DO), $\mathrm{pH}$, total dissolved solids (TDS), electrical conductivity (EC) and salinity were measured on site using a multiparameter meter (HACH, CO, USA). Determinations for total solids (TS), turbidity in nephelometric turbidity units $(\mathrm{NTU})$, chloride $(\mathrm{Cl})$, sulphate $\left(\mathrm{SO}_{4}\right)$, nitrate and nitrite, total phosphate (P), biochemical oxygen demand (BOD), total petroleum hydrocarbons diesel range organics (TPH-DRO), oil and grease, anionic surfactants as MBAS, free and saline ammonia and heavy metals including chromium $(\mathrm{Cr})$, copper $(\mathrm{Cu})$, lead $(\mathrm{Pb})$, nickel $(\mathrm{Ni})$ and zinc $(\mathrm{Zn})$ were done at Waterlab (Pty) Ltd (Pretoria, South Africa). Gas Chromatography with Photoionization Detection (GC/PID, Model Series 9000 H; Mocon-Baseline Series, Lyons, CO, USA) was used for detection and quantification of constituent petroleum fractions while the Inductively Coupled Plasma-Atomic Emission Spectrometer (ICP-AES, ACTIVA-M; Horiba Advanced Techno Co., Ltd., Kisshoin, Japan) method was used for metal analysis.

\section{Toxicity screening assessments}

Toxicity screening of the carwash effluent samples was done using toxicity testing kits as described in Table 1 (ToxSolutions, Kits and Services, Johannesburg, South Africa). The screening was carried out in environmentally controlled rooms using internationally standardised methods.

Table 1: Toxicity screening test methods and parameters used for carwash grab samples

\begin{tabular}{|l|l|l|l|l|}
\cline { 2 - 6 } \multicolumn{1}{c|}{} & \multicolumn{9}{c|}{ Test species } \\
\cline { 2 - 6 } & $\begin{array}{l}\text { Vibrio fischeri } \\
\text { (NRRL B-11177) }\end{array}$ & $\begin{array}{l}\text { Selenastrum } \\
\text { capricornutum (CCAP } \\
\text { 278/4 Cambridge, UK) }\end{array}$ & $\begin{array}{l}\text { Daphnia } \\
\text { magna }\end{array}$ & $\begin{array}{l}\text { Poecilia } \\
\text { reticulata }\end{array}$ \\
\hline Toxicity test & $\begin{array}{l}15 \text { and 30 min } \\
\text { bioluminescent } \\
\text { inhibition test }\end{array}$ & $\begin{array}{l}72 \mathrm{~h} \text { growth inhibition } \\
\text { test }\end{array}$ & $\begin{array}{l}24 \text { and 48 h } \\
\text { acute toxicity } \\
\text { test }\end{array}$ & $\begin{array}{l}\text { h } \\
\text { toxicity test }\end{array}$ \\
\hline Standard & EN ISO 11348-3: & OECD Guideline 201: & US EPA: US & EPA: \\
\hline
\end{tabular}




\begin{tabular}{|c|c|c|c|c|}
\hline method & $\begin{array}{l}2007 \text { (Lopez- } \\
\text { Roldan et al. 2012) }\end{array}$ & 1984 (OECD 1984) & $\begin{array}{ll}2002 & (\text { EPA } \\
2002 a) & \end{array}$ & $\begin{array}{ll}1996 & (\mathrm{EPA} \\
1996) & \end{array}$ \\
\hline $\begin{array}{l}\text { Exposure } \\
\text { period }\end{array}$ & 15 and 30 minutes & $72 \mathrm{~h}$ & 24 and $48 \mathrm{~h}$ & $96 \mathrm{~h}$ \\
\hline Test $\mathrm{T}^{\circ} \mathrm{C}$ & $15 \pm 1^{\circ} \mathrm{C}$ & $21-25^{\circ} \mathrm{C}$ & $21 \pm 2^{\circ} \mathrm{C}$ & $21 \pm 2^{\circ} \mathrm{C}$ \\
\hline Species age & - & - & $<24$ h old & $<21$ d old \\
\hline $\begin{array}{l}\text { Number of } \\
\text { test } \\
\text { organisms } \\
\text { per well } \\
\end{array}$ & - & $10^{4}$ cells $/ \mathrm{ml}$ & 5 & 5 \\
\hline $\begin{array}{l}\text { Replicate } \\
\text { number per } \\
\text { sample }\end{array}$ & 3 & 3 & 4 & 2 \\
\hline $\begin{array}{l}\text { Test sample } \\
\text { volume }\end{array}$ & $500 \mu \mathrm{l}$ & $25 \mathrm{ml}$ & $25 \mathrm{ml}$ & $200 \mathrm{ml}$ \\
\hline Test endpoint & $\begin{array}{l}\% \text { glow inhibition } \\
\text { or stimulation } \\
\text { relative to control }\end{array}$ & $\begin{array}{l}\text { \% growth inhibition or } \\
\text { stimulation relative to } \\
\text { control }\end{array}$ & \% mortality & \% mortality \\
\hline $\begin{array}{l}\text { Measuring } \\
\text { equipment }\end{array}$ & $\begin{array}{l}\text { Luminoscan TL, } \\
\text { Hygiene } \\
\text { Monitoring System }\end{array}$ & $\begin{array}{l}\text { Jenway } 6300 \\
\text { spectrophotomenter }\end{array}$ & $\begin{array}{l}\text { Visual } \\
\text { observation }\end{array}$ & $\begin{array}{l}\text { Visual } \\
\text { observation }\end{array}$ \\
\hline
\end{tabular}

Toxicity screening assays were done for all six carwash effluent grab samples using four test species for each sample. For the luminescence inhibition test, salinity was adjusted to 35 parts per thousand at $\mathrm{pH} 7$ while for the growth inhibition test; salinity was adjusted to 31 parts per thousand at $\mathrm{pH}$ 8.1. The test flasks were incubated with shaking at $100 \mathrm{rpm}$ with continuous illumination of $70 \mathrm{mE} / \mathrm{m} / \mathrm{s}$ using cool-white fluorescent lamps. In addition to other parameters indicated in Table 1, the $\mathrm{pH}$ of the test medium for both acute toxicity tests (daphnia and fish) was adjusted to 7.8 and, for all the toxicity screening tests, potassium dichromate was used as a positive control.

After the determination of the percentage effect (EP) obtained with each of the battery of toxicity screening tests performed, the samples were ranked into one of the following five classes following the descriptions of Persoone et al. (2003) as follows:

- Class I: $\quad$ No acute hazard - none of the tests shows a toxic effect.

- Class II: Slight acute hazard - a statistically significant percentage effect is reached in at least one test, but the effect level is below 50\%.

- Class III: Acute hazard - the percentage effect level is reached or exceeded in at least one test, but the effect level is below $100 \%$.

- Class IV: High acute hazard - the $100 \%$ percentage effect is reached in at least one test. 
- Class V: Very high acute hazard - the $100 \%$ percentage effect is reached in all the tests.

\section{Statistical analysis}

The statistical package for social sciences (IBM SPSS Statistics 22) was used for data analysis. Analysis of variance (ANOVA) was used to determine statistically significant differences in the concentration of pollutants in effluents collected from different carwashes at a 0.05 level of significance using the least significant difference (LSD) as the post hoc test. Descriptive statistics was used to generate the means and standard deviation for the data sets.

\section{Results and discussion}

Visually, almost all effluent samples looked greasy, oily and very turbid. The turbidity of the effluents ranged from 109 \pm 0.7 NTU in CW6 to $4000 \pm 29.7$ NTU in CW2. Turbidity is a measure of suspended particulate matter (TSS) in a water matrix, and in this case, TSS concentrations ranged from $612 \pm 6.4 \mathrm{mg} / \mathrm{l}$ to $16262 \pm 7.8 \mathrm{mg} / \mathrm{l}$. The high variation in turbidity of the samples could be due to the different car washing activities and cliental at the different sites and their contribution to turbidity; and also different wastewater pretreatment systems and efficiencies onsite at the carwash stations. On-site dissolved oxygen (DO) determinations using a multiparameter meter showed that samples contained very little DO ranging from $0.0 \mathrm{mg} / \mathrm{l}$ to 1.0 $\mathrm{mg} / \mathrm{l}$. The DO concentrations in wastewater are inversely correlated to chemical and organic pollution loads. Judging from the visual qualities of the wastewater effluents, the low levels of DO were largely expected.

The main concern with carwashes that use huge underground containers to collect carwash effluents is that in the event of leakages, total petroleum hydrocarbons (TPH) may move through the soil to the groundwater (Todd et al. 1999), especially TPH components like benzene, toluene, ethylbenzene, and xylene (BTEX) which exhibit high mobility in soils (Mckenna et al. 1995). This may result in TPH linked health concerns for people who depend on borehole water for domestic use since it is usually assumed safe and therefore not subject to frequent water quality monitoring as is the case with surface water. Spill prevention and implementation of management best practices remain the best remedy against any such occurrences.

Physicochemical analysis of the effluent samples revealed that the concentration of nutrients was negligible, being $<0.2 \mathrm{mg} / \mathrm{l}$ for nitrates and $<0.1 \mathrm{mg} / \mathrm{l}$ for nitrites in all carwash effluents. The concentration of phosphates in carwash effluents ranged between 0.8 and $5.2 \mathrm{mg} / \mathrm{l}$ except for effluents from CW2 where it was $24 \mathrm{mg} / \mathrm{l}$. The environmental standards decided by the French legislation for surface water set values of 10 and $30 \mathrm{mg} / \mathrm{l}$ respectively for total phosphate and total nitrogen concentrations in carwash wastewater effluents destined for discharge into freshwater systems (Sablayrolles et al. 2010). Therefore, with respect to observed nutrient concentration, it is unlikely that these carwash effluents could have resulted in eutrophication in receiving water bodies in the event of direct discharge. The total concentration of TPH-BTEX 
and diesel range organics (DRO) (TPH-BTEX-DRO) was $<0.1 \mathrm{mg} / \mathrm{l}$ in all effluent samples. BTEX compounds are largely thought to result in neurological health problems, with benzene being classified in EPA Group A (carcinogen) (Pawlak et al. 2008). The concentration of each of the TPH-BTEX compounds in carwash effluent samples was $<0.005 \mathrm{mg} / \mathrm{l}(\mathrm{ppm})$, more than 10 times less than the minimal risk level (MRL) of $0.05 \mathrm{ppm}$ for benzene, $3 \mathrm{ppm}$ for toluene, $1 \mathrm{ppm}$ for p-xylene and $0.2 \mathrm{ppm}$ for ethylbenzene (Todd et al. 1999). The effluents were therefore unlikely to cause any adverse health effects to humans with respect to BTEX compounds. However, the minimal risk level of BTEX compounds to aquatic fauna is unknown and may be different from that of humans and until it is clearly defined, the discharge of effluents containing BTEX compounds into receiving aquatic bodies needs to be restricted and only done with proper monitoring in order to detect the earliest signs of distress. The concentration of total petroleum hydrocarbons (TPH) ranged from $<0.01 \mathrm{mg} / \mathrm{l}$ in CW6 to $7.6 \mathrm{mg} / \mathrm{l}$ in CW2. This concentration is way above the concentration range of 0.02-0.56 mg/l reported by Sablayrolles et al. (2010) in pre-treated commercial carwashes in France. TPHs are contaminants of environmental and public health concern as many are carcinogenic, environmentally persistent and/or toxic (Waters 2011). Due to their low density compared to water, TPHs form a layer on the surface of the water, hindering the penetration of oxygen into water bodies and thereby creating temporary hypoxic conditions. Besides, the discharge of effluents with high concentrations of TPHs into surface water bodies may result in elevated BOD due to an increase in hydrocarbon consuming bacteria (Waters 2011).

The results of other physicochemical analyses are presented in Table 2 while the concentrations of gasoline range organics and heavy metal elements are given in Figure 2 and 3 respectively.

Table 2: Physicochemical qualities of carwash effluents

\begin{tabular}{|l|l|l|l|l|l|l|}
\cline { 2 - 7 } \multicolumn{1}{c|}{} & \multicolumn{6}{c|}{ Parameter levels (Mean \pm SD) } \\
\hline Parameters & CW1 & CW2 & CW3 & CW4 & CW5 & CW6 \\
\hline pH & $8.6 \pm 0.1$ & $7.2 \pm 0.2$ & $7.5 \pm 0.1$ & $7.7 \pm 0.2$ & $7.3 \pm 0.2$ & $7.5 \pm 0.3$ \\
\hline EC (mS/m at $\left.25^{\circ} \mathrm{C}\right)$ & $122 \pm 2.1$ & $83.2 \pm 1.9$ & $52 \pm 2.8$ & $50.6 \pm 1.7$ & $40.9 \pm 0.3$ & $28.1 \pm 0.9$ \\
\hline TS (at $\left.105^{\circ} \mathrm{C}(\mathrm{mg} / \mathrm{l})\right)$ & $1058 \pm 19.8$ & $16262 \pm 7.8$ & $818 \pm 3.5$ & $756 \pm 2.1$ & $612 \pm 6.4$ & $892 \pm 13.4$ \\
\hline $\begin{array}{l}\text { TDS (at } 180^{\circ} \mathrm{C} \\
(\mathrm{mg} / \mathrm{l}) \text { ) }\end{array}$ & $686 \pm 8.5$ & $468 \pm 13.4$ & $506 \pm 5.7$ & $482 \pm 13.4$ & $362 \pm 8.5$ & $188 \pm 4.9$ \\
\hline Turbidity in N.T.U & $382 \pm 3.5$ & $4000 \pm 29.7$ & $372 \pm 7.8$ & $455 \pm 8.5$ & $246 \pm 7.8$ & $109 \pm 0.7$ \\
\hline BOD (mg/l) & $354 \pm 9.2$ & $650 \pm 4.9$ & $204 \pm 4.2$ & $114 \pm 3.5$ & $192 \pm 6.4$ & $27 \pm 2.1$ \\
\hline $\mathrm{Cl}(\mathrm{mg} / \mathrm{l})$ & $64 \pm 3.5$ & $40 \pm 1.4$ & $32 \pm 3.5$ & $27 \pm 2.1$ & $26 \pm 2.1$ & $14 \pm 2.8$ \\
\hline $\mathrm{SO}_{4}$ (mg/l) & $184 \pm 2.1$ & $6 \pm 2.1$ & $144 \pm 5.7$ & $149 \pm 3.5$ & $34.5 \pm 3.5$ & $12.5 \pm 3.5$ \\
\hline
\end{tabular}




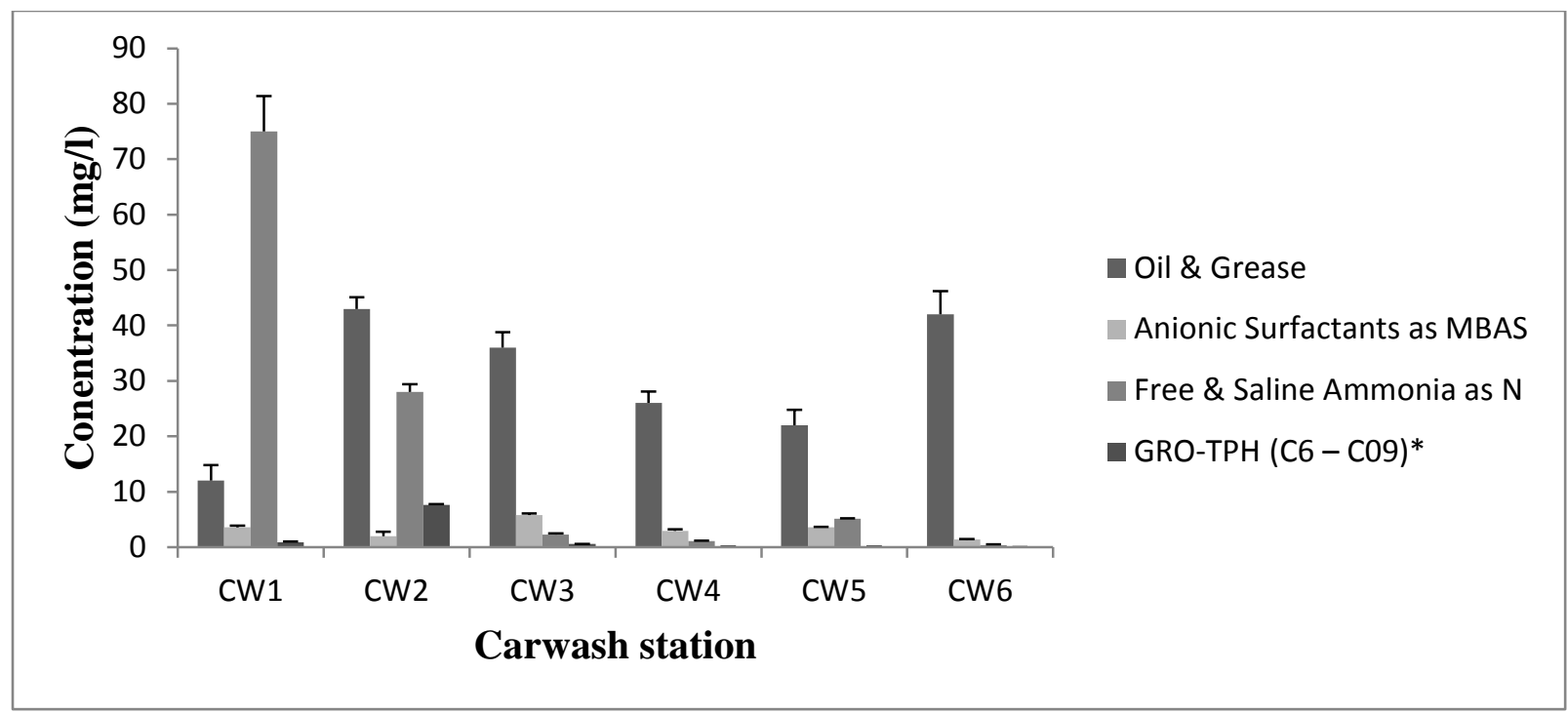

Figure 2: Concentrations of TPH-GRO and ammonia in carwash effluents

*C6-C12 defines the range of gasoline in total petroleum hydrocarbons (Pawlak et al. 2008).

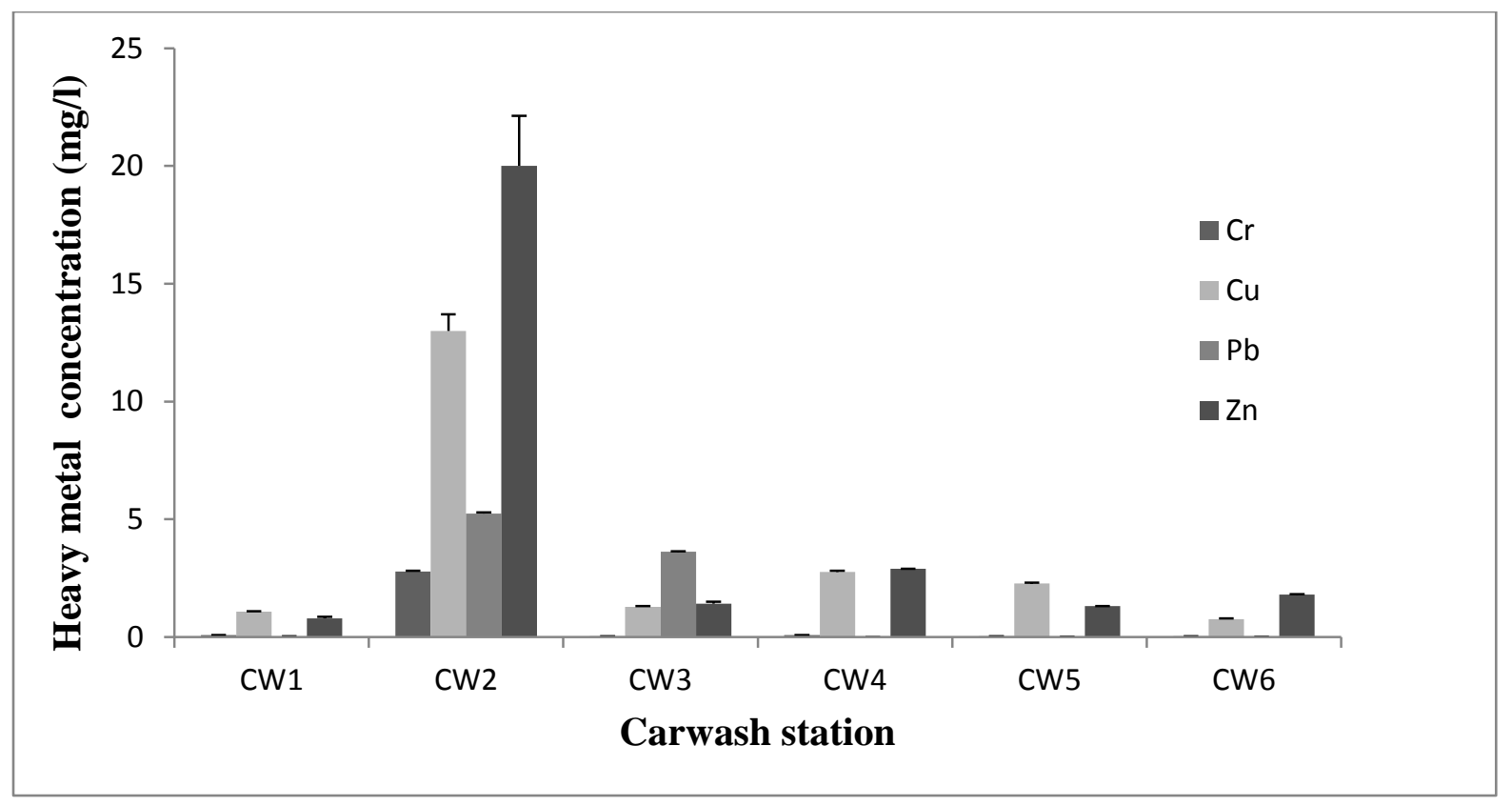

Figure 3: Concentrations of heavy metals in carwash effluents

The concentration of oil and grease in effluents from CW2, 3 and 6 (43, 36 and $42 \mathrm{mg} / \mathrm{l}$ respectively) [Figure 2] exceeded the $25 \mathrm{mg} / \mathrm{l}$ limit for petroleum based oil and grease set by Water Environment Federation in 1973 (Driscoll et al. 1994) while the concentration in CW4 marginally exceeded the limit. However, this limit varies with municipalities depending on the 
type of sewers, sewer flow rates and the history of grease related clogs (Pawlak et al. 2008). The most important synthetic anionic surfactants are linear alkybenzene sulphonates (LAS) which are the principal constituents of detergents used in the carwash industry (Sablayrolles et al. 2010). LAS have been found to have carcinogenic and reproductively toxic by-products, and to be persistent in the environment (Oknich 2002; Waters 2011). Their decomposition also consumes bio-available oxygen which may partly explain the high BOD values that were observed in this study. Besides, LAS contribute to the permeation of other pollutants like organic chemicals, pesticides and phenols into aquatic animals by lowering the surface tension of water at a concentration of $2 \mathrm{mg} / \mathrm{l}$, making them significant environmental pollutants (Sablayrolles et al. 2010). Detergents have been found to be toxic to fish at $15 \mathrm{mg} / \mathrm{l}$, and to kill fish eggs at $5 \mathrm{mg} / \mathrm{l}$ (Oknich 2002). Environmental problems caused by LAS-containing detergents can be reduced or solved by using biodegradable and phosphate free detergents (EPA 2004).

Figure 3 shows that copper $(\mathrm{Cu})$ and zinc $(\mathrm{Zn})$ were the most abundant of the heavy metals in carwash effluent. These results tally with the observations of Moores et al. (2010) who reported that $\mathrm{Zn}$ and $\mathrm{Cu}$ are the highest metal contaminants in carwash effluents, derived mainly from tyres and brakepads respectively (Oknich 2002). While metals occur naturally in most freshwater systems and are important to biological processes, elevated concentrations are detrimental to aquatic ecosystems (Waters 2011). Waters (2011) also reported acute toxicities $\left(\mathrm{LC}_{50}\right)$ of 0.0025$0.755 \mathrm{mg} / \mathrm{l}$ of $\mathrm{Cu}$ against Daphnia magna after $48 \mathrm{~h}$ of exposure and 0.0096-0.9 mg/l against fish after $96 \mathrm{~h}$ of exposure while for Zn; the reported LC $_{50}$ was 0.068-3.290 mg/l against Daphnia magna and 0.238-2.66 mg/l against fish after $48 \mathrm{~h}$ and $96 \mathrm{~h}$ of exposure respectively. The observed concentrations in this study far exceeded the lower limits of the $\mathrm{LC}_{50}$ values for both $\mathrm{Cu}$ and $\mathrm{Zn}$ which may also have contributed to the observed mortalities of both the fish and daphnia (Table 3). The findings of this research seem to concur with the observations of O’Sullivan et al. (2011) that carwash wastewater is predominantly characterised by pollutants such as Zn, Cu and TPH.

Toxicity screening procedures assumed an in vivo approach where whole organisms were exposed to original wastewater samples without any sample enrichment, and using organisms at different trophic levels to obtain a better evaluation and integrative effects on whole organisms. Results indicated a high acute hazard (Class IV) for all effluent samples (Table 3). The 100\% mark was reached in the Daphnia and Poecilia acute toxicity tests while the bioluminescence and growth inhibition tests fell slightly short of the $100 \%$ mark. Acute lethality is an obvious and easy to observe evaluation of toxicity of either pure compounds or complex effluents.

Table 3: Carwash effluent toxicity screening assay results

\begin{tabular}{|l|l|l|l|l|l|l|}
\cline { 2 - 7 } \multicolumn{1}{c|}{} & \multicolumn{6}{c|}{ Effluent sample from } \\
\hline Tests & CW1 & CW2 & CW3 & CW4 & CW5 & CW6 \\
\hline $\begin{array}{l}15 \text { min Vibrio fischeri } \\
\text { bioluminescent screening }\end{array}$ & -93 & -65 & -90 & -75 & -93 & -9 \\
\hline
\end{tabular}




\begin{tabular}{|l|l|l|l|l|l|l|}
\hline $\begin{array}{l}\text { test (\% growth inhibition (- } \\
\text { ) or stimulation (+)) }\end{array}$ & & & & & & \\
\hline $\begin{array}{l}30 \text { min Vibrio fischeri } \\
\text { bioluminescent screening } \\
\text { test (\% growth inhibition (- } \\
\text { or stimulation (+)) }\end{array}$ & -94 & -89 & -79 & -91 & -6 \\
\hline $\begin{array}{l}72 \quad \text { h Selenastrum } \\
\text { capricornutum growth } \\
\text { inhibition screening test (\% } \\
\text { growth inhibition (-) or } \\
\text { stimulation (+)) }\end{array}$ & -95 & -157 & -208 & -154 & -147 & -108 \\
\hline $\begin{array}{l}24 \text { h Daphnia magna acute } \\
\text { toxicity screening test (\% } \\
\text { mortality) }\end{array}$ & 100 & 100 & 100 & 100 & 100 & 100 \\
\hline $\begin{array}{l}\text { 48 haphnia magna acute } \\
\text { toxicity screening test (\% } \\
\text { mortality) }\end{array}$ & 100 & 100 & 100 & 100 & 100 & 100 \\
\hline $\begin{array}{l}\text { 96 h Poecilia reticulata } \\
\text { acute toxicity screening test } \\
\text { (\% mortality) }\end{array}$ & 100 & 100 & 100 & 100 & 100 & 100 \\
\hline $\begin{array}{l}\text { Hazardous classification } \\
\text { for screening test results }\end{array}$ & Class IV & Class IV & Class IV & Class IV & Class IV & Class IV \\
\hline Class and weight score & $-83 \%$ & $-92 \%$ & $-92 \%$ & $-92 \%$ & $-92 \%$ & $-75 \%$ \\
\hline
\end{tabular}

In vivo toxicity screening bioassays provide conclusive information about the biological and potential ecological effects of test media on parameters such as growth, fecundity and survival/mortality since they integrate the effects of all substances like chemicals, nutrients, heavy metals and toxins present in a the test medium (Kienle et al. 2011). The downside of in vivo toxicity bioassays is that they give limited information about the substance or substances responsible for an observed effect. However, looking at Table 3, the concentration of free and saline ammonia was high in almost all effluent samples with the exception of CW4 and CW6. Documented evidence shows that early life stages of fish are very sensitive to ammonia (US.EPA 2009), with concentrations of as low as $0.04 \mathrm{mg} / \mathrm{l}$ having been observed to cause histopathological effects in rainbow trout after long exposure (EPA 2002b). The US.EPA (2009) recommends a chronic quality criterion of $0.521 \mathrm{mg} / \mathrm{l}$ of ammonia where early life stages of fish are present in freshwater systems.

Exceptionally high BOD concentrations (range 114-650 mg/l) were observed in five of the effluent samples, with only CW6 (27 mg/l) complying with the WHO guideline value of $30 \mathrm{mg} / \mathrm{l}$ (Danha et al. 2014). While this observation has partly been attributed to the presence of LAS in effluent samples, high BOD is also an index of organic pollution in a water matrix (Adedolapo and Olajumoke 2012). If large amounts of such effluents are discharged into environmental water bodies, increased aerobic microbial decomposition of organic matter could lead to hypoxic 
conditions which could in turn lead to a number of negative effects ranging from reproductive failure in adult fish to mortality in juveniles (Elshout et al. 2013). While the dissolved oxygen concentrations during the course of the toxicity screening assays were maintained by means of aeration (where necessary), the occurrence of oxygen deficient conditions in natural water courses as a result of effluent discharge may result in increased sensitivity of aquatic organisms to toxins, resulting in reduced survival rates.

The design of toxicity screening in this study was such that only acute toxicity data was obtained. This needs to be followed up by definitive tests in order to obtain chronic toxicity data of the effluents, which would provide the dose-response information and so help draw guidelines or limits that are relevant to the study area and to the test species used.

The big range in parameter concentrations observed in this study reflects differences in the efficiency of the pre-treatment systems used by these carwashes in pollutant removal from effluents. Statistical analysis using ANOVA showed that in the majority of cases, there were significant differences $(P<0.05)$ in the concentration of pollutants in effluents collected from different carwashes. Notable departures from this trend where mean parameter concentrations/levels did not significantly differ $(P>0.05)$ were observed for: $\mathrm{pH}$ for effluents from CW2-CW6; EC for effluents from CW3 and CW4; TDS for effluents from CW2 and CW4, CW3 and CW4; turbidity for effluents from CW1 and CW3; oil and grease for effluents from CW2 and CW6, and CW4 and CW5; Zn for effluents from CW1 and 3, 5 and 6, CW3 and 4, 5 and 6, CW4 and 5 and 6, and CW5 and CW6. All selected carwashes in this study used high pressure technology for car washing yet the quality of their effluents significantly differed in the concentration of most key parameters. Ironically, almost all carwashes in this study indicated that they used car shampoo, heavy duty engine cleaner, tyre and bump wax and degreasers in their operations which, coupled with the same wash technology could have resulted in effluent of almost the same quality, which was not the case. There was also no correlation of effluent quality to carwash location, with carwashes in the same locality producing significantly different effluent quality. The differences in the quality of their effluents could therefore be reflective of either a lack of standardised operating procedures in the car wash industry or a lack of best management practices among different players in the industry.

The approach used in toxicity assays in this study was limited in that it could not pinpoint the exact cause of toxicity that was observed. Future studies of this kind may need to adopt a deterministic approach with the use of substance specific filtration membranes where potential toxicants can then be screened one at a time to determine which one of them is responsible for acute toxicity. This approach may help in remediation efforts since the carwash operators will know which pollutant(s) they need to remove from their effluents.

\section{Conclusion}


The findings of this study prove that carwash effluents are a potential public and environmental health hazard. Considering the dearth of information on monitoring and water quality discharge guidelines for the carwash waste water effluent in South Africa, this study provides a basis for which the Department of Water Affairs can take serious considerations for legislating this industry to ensure public and environmental health protection. There is need for municipal authorities to enforce environmental bylaws governing the operations of carwashes in Gauteng and indeed in South Africa as a way of making sure that business operators adopt best management practices which are essential in addressing root causes of surface water pollution. Further work is needed to determine the exact causes of carwash effluent toxicity as a step towards remediation efforts aimed at tackling the toxicity of effluents to aquatic organisms and protection of public health.

\section{Acknowledgements}

This research was supported through a grant from the University of South Africa, through the Women in Research funding to Prof M. Tekere. The authors thank Waterlab, Pretoria, South Africa and ToxSolutions, Kits and Services for their assistance with the analysis of the samples. The assistance and involvement of research group team members, Ms M. Mtlatla, Mr MM. Sebaiwa, Mr ND. Baloyi, Dr A. Kamika, Dr R. Selvarajan and Mr B. Ngauegang during the project is acknowledged.

\section{References}

Adedolapo A, Olajumoke OA (2012) Impacts of Effluents on the Limnology of a Tropical River , Southwestern Nigeria. J Appl Sci Environ Manag 16:201 - 207.

ArriveAlive (2010) How many vehicles are in South Africa November 2010?

Baa-Poku J, Asante F, Amakye JS (2013) Impact of urban effluents on the macroinvertebrates of a Creek in Accra, Ghana. West African J Appl Ecol 21:97-109.

Brown C (2002) Water Effluent and Solid Waste Characteristics In The Professional Car Wash Industry: A Report for the International Carwash Association. 28.

Bursztynsky TA, Scofield R (1982) Oil and grease in stormwater runoff. Environ Sci Eng 1-252.

Danha C, Utete B, Soropa G, Rufasha SB (2014) Potential Impact of Wash Bay Effluent on the Water Quality of a Subtropical River. J Water Resour Prot 6:1045-1050.

Diphare MJ, Pilusa J, Muzenda E, Mollagee M (2013) A Review of Waste Lubricating Grease Management. 2nd International Conference on Environment, Agriculture and Food Sciences (ICEAFS’2013) August 25-26, 2013 Kuala Lumpur (Malaysia). 
Driscoll TP, Eysenbach E, Joyce MW, et al (1994) Pretreatment of Industrial Wastes. Manual of Practice No. FD-3. Water Environment Federation

Elshout PMF, Dionisio Pires LM, Leuven RSEW, et al (2013) Low oxygen tolerance of different life stages of temperate freshwater fish species. J Fish Biol 83:190-206. doi: $10.1111 / \mathrm{jfb} .12167$

EPA (2002a) Methods for Measuring the Acute Toxicity of Effluents and Receiving Waters to Freshwater and Marine Organisms Fifth Edition October 2002. 1200 Pennsylvania Avenue, NW Washington, DC 20460

EPA (1996) Ecological Effects Test Guidelines. OPPTS 850.1075 Fish Acute Toxicity Test, Freshwater and Marine. Washington, DC 20460

EPA (2004) Stormwater Management for Wash Bays. EPA 517/04, South Australia.

EPA (2002b) Short-term Methods for Estimating the Chronic Toxicity of Effluents and Receiving Waters to Freshwater Organisms (Fourth Edition). 1200 Pennsylvania Avenue, NW Washington, DC 20460

Fall C (2007) Carwash wastewaters: characteristics, volumes, and treatability by gravity oil separation. Rev Mex 6:175-184.

Gryta M, Karakulski K, Morawski AW (2001) Purification of oily wastewater by hybrid UF/MD. Water Res 35:3665-3669. doi: 10.1016/S0043-1354(01)00083-5

Haddis A, Getahun T, Mengistie E, et al (2014) Challenges to surface water quality in mid-sized African cities: Conclusions from Awetu-Kito Rivers in Jimma, south-west Ethiopia. Water Environ J 28:173-182. doi: 10.1111/wej.12021

Ilemobade AA, Adewumi JR, Van Zyl JE (2009) Framework for assessing the viability of implementing dual water reticulation systems in South Africa. Water SA 35:216-227.

Kienle C, Kase R, Werner I (2011) Evaluation of bioassays and wastewater quality. In vitro and in vivo bioassays for the performance review in the Project "Strategy MicroPoll". Swiss Centre for Applied Ecotoxicology, Eawag-EPFL, Duebendorf. Dübendorf

Lau WJ, Ismail a. F, Firdaus S (2013) Car wash industry in Malaysia: Treatment of car wash effluent using ultrafiltration and nanofiltration membranes. Sep Purif Technol 104:26-31. doi: 10.1016/j.seppur.2012.11.012

Lopez-Roldan R, Kazlauskaite L, Ribo J, et al (2012) Evaluation of an automated luminescent bacteria assay for in situ aquatic toxicity determination. Sci Total Environ 440:307-313. doi: 10.1016/j.scitotenv.2012.05.043

Marshall R (1998) Laboratory guidance and whole effluent toxicity test review criteria. Olympia, 
Washington 98504-7710

Mazumber D, Mukherjee S (2011) Treatment of automobile service station wastewater by coagulation and activated sludge process. Int J Environ Sci Dev 2:64-69. doi: 10.7763/IJESD.2011.V2.98

Mckenna EA, Youngren SH, Baker SR, et al (1995) Evaluation of the total petroleum hydrocarbon (TPH) standard for JP-4 jet fuel. Soil Sediment Contam 4:355-406. doi: 10.1080/15320389509383505

Mohamed RMSR, Kutty NMAI, Kassim AHM (2014) Efficiency of Using Commercial and Natural Coagulants in Treating Car Wash Wastewater. Aust J Basic Appl Sci 8:227-234.

Moores J (Niwa), Pattinson P (Niwa), Hyde C (Niwa) (2010) Enhancing the control of contaminants from New Zealand's roads : results of a road runoff sampling programme. New Zealand Transport Agency research report. Auckland

NAAMSA (2015) NAAMSA Online. Lead. Auth. Inf. Provid. South African Mot. Ind.

O’Sullivan A, Smalley D, Good J (2011) Quantifying the impact of car washing on water quality and assessing simple treatment strategies. Christchurch, New Zealand

OECD (1984) “Alga, Growth Inhibition Test” 201. OECD guideline for testing of chemicals. Washington DC

Oknich J (2002) The Perceived Environmental Impact of Car Washing. Ramsey-Washington Metro Watershed District

Pawlak Z, Rauckyte T, Oloyede A (2008) Oil, grease and used petroleum oil management and environmental economic issues. J Achiev Mater Manuf Eng 26:11-17.

Persoone G, Marsalek B, Blinova I, et al (2003) A practical and user-friendly toxicity classification system with microbiotests for natural waters and wastewaters. Environ Toxicol 18:395-402. doi: 10.1002/tox.10141

Randles K, Mazur L, Milanes C (2007) A Review of the Potential Human and Environmental Health Impacts of Synthetic Motor Oils a Review of the Potential Human and Environmental Health Impacts. California

Rogerson CM (2002) Urban tourism in the developing world: The case of Johannesburg. Dev South Afr 19:169-190. doi: 10.1080/03768350220123927

Sablayrolles C, Vialle C, Vignoles C, Montrejaud-Vignoles M (2010) Impact of carwash discharge on stormwater quality (Toulouse, France). Water Sci Technol 62:2737-2746. doi: 10.2166/wst.2010.929

SouthAfrica.info (2012) South Africa. Br. Med. J. 2:190-191. 
Todd DG, Chessin RL, Colman J (1999) Toxicological Profile for Total Petroleum Hydrocarbons (Tph). U.S. Department of Health and Human Services. Public Health Service Agency for Toxic Substances and Disease Registry.

US.EPA (2009) Draft 2009 Update - Aquatic Life Ambient Water Quality Criteria for Ammonia - Freshwater. Washington, DC

Waters S (2011) Getting the stormwater message across Supporting information on the effects of selected residential Activities on Stormwater Quality (with particular reference to the aquatic ecosystems of the Avon River/Ōtākaro and Heathcote River/Ōpāwaho in Christchurch. Christchurch, New Zealand

Zaneti R, Etchepare R, Rubio J (2012) More environmentally friendly vehicle washes: Water reclamation. J Clean Prod 37:115-124. doi: 10.1016/j.jclepro.2012.06.017 